\title{
OPTIMALISASI DESAIN AKUISISI SEISMIK 3D LAUT DENGAN MENGGUNAKAN METODE DINAMIK PADA MODEL GEOLOGI 3D DAERAH NEJB
}

\author{
Haryo Bimo Wicaksono, Firman Syaifuddin, Mariyanto Mariyanto \\ Departemen Teknik Geofisika, Fakultas Teknik Sipil, Perencanaan dan Kebumian, \\ Institut Teknologi Sepuluh Nopember \\ e-mail : bimowicaksono97@gmail.com
}

\begin{abstract}
Abstrak. Akuisisi data seismik merupakan tahap awal dalam metode seismik dan kualitas data sangat berpengaruh pada tahap-tahap selanjutnya. Dalam memperoleh data yang sesuai dengan target, penentuan desain akuisisi seismik harus baik sehingga perlu dilakukan optimalisasi. Penelitian ini dilakukan dengan tujuan mendapatkan desain akuisisi seismik 3D yang optimal menggunakan metode statik dan dinamik serta membandingkan pengaruh pada metode statik dan dinamik. Parameter desain akuisisi seismik 2D, yaitu CDP interval, fold coverage, dan far offset yang kemudian digunakan pada desain akuisisi seismik 3D laut dengan dengan variasi parameter jumlah streamer, interval streamer, dan interval hydrophone. Parameter input didapatkan dengan pendekatan matematis. Metode statik menggunakan perambatan gelombang dengan asumsi kondisi bawah permukaan adalah datar (flat), sedangkan metode dinamik dilakukan dengan simulasi ray tracing pada model geologi. Desain akuisisi seismik 3D optimal yang didapakan antara lain jumlah streamer 8 buah, interval streamer $200 \mathrm{~m}$, interval hydrophone $12.5 \mathrm{~m}$ dengan jumlah 360/streamer, interval shot $50 \mathrm{~m}$, dan interval lintasan $800 \mathrm{~m}$ yang dilakukan dengan konfigurasi survei tipe sail line. Ukuran bin yang digunakan $6.25 \mathrm{~m} \times 100 \mathrm{~m}$ dengan didapatkan nilai fold coverage 45 dan far offset $4500 \mathrm{~m}$. Berdasarkan hasil analisis, metode dinamik juga perlu diaplikasikan daripada pengaplikasian metode statik saja, dikarenakan pengoptimalan metode dinamik dilakukan dengan simulasi ray yang lebih mendekati kondisi sebenarnya.
\end{abstract}

Kata Kunci: Desain akuisisi seismik 3D laut; simulasi gelombang; sail line; streamer

\begin{abstract}
Seismic data acquisition is an initial stage in seismic methods and data quality is very influential in later stages. In obtaining data that is in accordance with the target, the determination of the seismic acquisition design must be good so that it needs to be optimized. This research was conducted with the aim of obtaining optimal 3D seismic acquisition design using static and dynamic methods and comparing the effects on static and dynamic methods. 2D seismic acquisition design parameters, such as CDP intervals, fold coverage, and far offset which are then used in the design of marine 3D seismic acquisition with variations in the number of streamer parameters, streamer intervals, and interval hydrophones. Input parameters are obtained by a mathematical approach. Static methods use wave propagation assuming the subsurface conditions are flat, while the dynamic method is done by ray-tracing simulation on the geological model. The optimal 3D seismic acquisition design that was achieved included the number 8 streamers, 200 $m$ of streamer interval, $12.5 \mathrm{~m}$ of hydrophone interval with number 360/streamer, $50 \mathrm{~m}$ of interval shot and $800 \mathrm{~m}$ of line interval that was carried out with a sail line type survey configuration. The bin size used is 6.25 $m \times 100 \mathrm{~m}$ with fold coverage 45 and far offset $4500 \mathrm{~m}$. Based on the results of the analysis, dynamic methods need to be carried out rather than static methods only, because optimization using the dynamic method is done by ray simulation that is closer to the actual condition.
\end{abstract}

Keywords: 3D marine seismic acquisition design; wave simulation; sail line; streamer

\section{PENDAHULUAN}

Desain survei seismik merupakan tahapan dalam pemilihan parameter akuisisi data seismik dengan mempertimbangkan target yang akan dicapai dan masalah-masalah yang akan timbul saat proses akuisisi data (Lubis dan Mulyatno, 2018). Penentuan parameter akuisisi yang diterapkan akan sangat berpengaruh terhadap kualitas data seismik yang diperoleh (Chaouch dan Mari, 2006). Desain akuisisi dengan menggunakan metode dinamik mampu memberikan informasi mengenai maksimum offset, kerapatan perambatan gelombang, dan mengetahui perambatan gelombang bawah permukaan yang dipengaruhi oleh kondisi bawah permukaan (Banuboro, 2017). Menuru (Wibisono dkk., 2018), hasil desain akuisisi 
dengan menggunakan dinamik lebih baik dibandingkan dengan hanya menggunakan metode statik (Wibisono dkk., 2018). Penelitian ini bertujuan untuk mendapatkan desain akuisisi seismik yang optimal dan dapat mengetahui pengaruh desain akuisisi 3D metode statik dan dinamik. Data input merupakan model geologi 3D yang terletak pada perairan Timur Pulau Madura.

Terdapat parameter input yang dibutuhkan dengan pendekatan matematis. Pada seismik 2D terdapat parameter CDP interval, fold coverage, dan far offset. Parameter Interval CDP (common dip point) ini sama halnya dengan pengertian midpoint. Midpoint merupakan titik yang jatuh tepat ditengahtengah antara posisi sumber dengan penerima (Cordsen dkk., 2000)

$$
\text { Interval } C D P=\frac{V r m s}{4 \times f \max \times \operatorname{Sin} \alpha}
$$

dengan:

Vrms: Kecepatan rata-rata $(\mathrm{m} / \mathrm{s})$

Fmax: Frekuensi maksimal gelombang (hz)

Sina: Kemiringan target

Berbeda dengan seismik 2D, Pada seismik 3D laut titik pantul sebuah sinar gelombang pada lapisan bawah permukaan adalah berupa bidang atau area disebut dengan bin size.

Crossline bin size $=\frac{\text { Streamer interval }}{2 \times \text { Number of Sources }}$

Inline bin size $=\frac{1}{2} x$ Interval Channel dengan:

Streamer interval: Jarak antar streamer $(\mathrm{m})$ Interval channel: Jarak antar hydrophone $(\mathrm{m})$ Number of Source: Jumlah source pada seismic vessel

Pada seismik 2D, parameter fold coverage merupakan banyaknya gelombang yang memantul pada titik CDP yang sama, secara matematis dapat didefinisikan dengan persamaan berikut:

$$
\text { Fold Coverage }=\frac{1}{2} \times \frac{R I}{S I} \times C h
$$

dengan:

$\mathrm{RI}$ : Receiver interval (m) http://dx.doi.org/10.12962/j25023659.v6i1.5450
SI: Shot interval (m)

Ch: Jumlah receiver

Nilai fold coverage pada survei seismik 3D dibedakan menjadi cross line fold dan inline fold. Namun, pada seismik 3D laut crossline fold bernilai 1 (satu) karena receiver bergerak dengan source mengikuti shot line sehingga fold yang dihasilkan hanya merupakan inline fold. Inline fold dapat dihitung dengan menggunakan persamaan berikut: dengan:

$$
\text { Inline Fold }=\frac{\Sigma C h \times \text { Channel Interval }}{2 \times \text { Shot Interval }}
$$

$\Sigma \mathrm{Ch}$ : Jumlah hydrophone

Channel interval: jarak antar hydrophone (m)

Shot interval: jarak antar shot $(\mathrm{m})$

Parameter far offset merupakan rekaman gelombang terjauh antara source dengan receiver. far offset difokuskan untuk mendapatkan target kedalaman (Cordsen dkk., 2000). Parameter far offset pada seismik laut dengan konfigurasi off end umumnya merupakan panjang bentangan streamer, ketika sudah diketahui panjang bentangan lintasan maka dapat dihitung banyaknya receiver yang akan digunakan pada survei.

dengan:

$$
\Sigma C h=\frac{\text { Far Offset }}{\Delta R}
$$

$\boldsymbol{\Sigma}$ Ch: Jumlah hydrophone

$\Delta \mathrm{R}$ : Interval hydrophonr $(\mathrm{m})$

\section{METODOLOGI}

Dapat dilihat pada Gambar 1, Data input pada penelitian ini merupakan model geologi 3D sintetik yang sudah serta satu buah data sumur PJG-1. Model geologi terbentuk dalam domain kedalaman, memiliki 12 (dua belas) batas lapisan dengan nilai kecepatan interval $(\mathrm{Vp})$ dan densitas setiap lapisan. Model geologi 3D memiliki ukuran E-W $26800 \mathrm{~m}$ dan $\mathrm{N}-\mathrm{S} 16500 \mathrm{~m}$, model geologi 3D tersebut dapat dibuat menjadi model geologi 2D dengan melakukan slicing Barat-Timur yang berpotongan pada data sumur. 


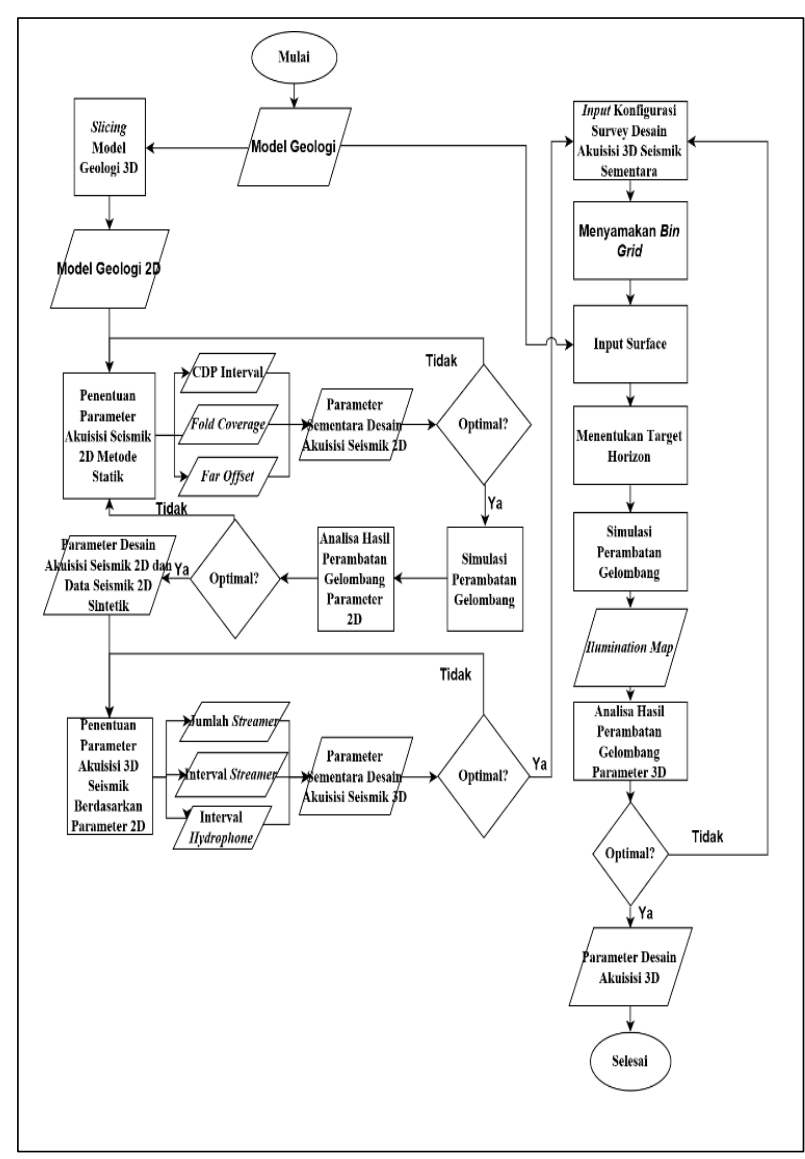

Gambar 1. Diagram Alir Penelitian

Desain akusisi seismik 2D yang optimal dilakukan dengan tinjauan parameter berupa $C D P$ Interval, Fold Coverage, dan Far Offset. Desain akuisisi seismik 2D dilakukan dengan metode dinamik. Desain akuisisi seismik 2D metode dinamik dipengaruhi kondisi bawah permukaan karena dilakukan dengan melihat respon perambatan gelombang pada model geologi 2D dari hasil slicing. Perambatan gelombang dilakukan dengan kondisi ideal tanpa adanya atenuasi frekuensi maupun amplitudo. Hasil perambatan gelombang setiap variasi parameter kemudian diolah secara sederhana hingga menjadi penampang seismik 2D sintetik dan dianalisa secara kualitatif, dimana hasil olahan yang mampu menggambarkan reflektor yang dengan jelas, dianggap sebagai desain akusisi seismik 2D yang optimal. Desain akusisi seismik 2D tersebut diaplikasikan pada penentuan parameter desain akuisisi seismik 3D.

Desain akusisi seismik 3D menggunakan metode statik dan dinamik. Terdapat variasi parameter yang digunakan pada desain akuisisi seismik 3D ini yaitu jumlah streamer, interval streamer, interval hydrophone dengan memperhatikan parameter desain akuisisi seismik 2D yang paling optimal. Desain akuisisi seismik 3D metode statik dengan melihat ditribusi trace pada target kedalaman. Parameter desain akuisisi seismik 3D metode dinamik dilakukan simulasi gelombang dengan menggunakan kondisi bawah permukaan dari model geologi 3D yang telah ada dengan parameter kecepatan lapisan ( $\mathrm{Vp}$ ) dan densitas lapisan. Simulasi gelombang pada metode dinamik ini dilakukan sebagai analisa nilai fold terhadap pengaruh kondisi bawah permukaan.

\section{HASIL DAN PEMBAHASAN}

Penentuan parameter input desain akuisisi data seismik 2D diawali dengan penentuan CDP interval menggunakan persamaan (1) yang kemudian didapatkan parameter interval receiver dan shot dengan dengan hubungan yaitu dua kali dari $C D P$ interval (Cordsen dkk., 2000). Kedalaman target pada penelitian ini yaitu lapisan basement, Vrms pada model geologi didapatkan sebesar $3243.171 \mathrm{~m} / \mathrm{s}$ dari analisa kuantitatif kecepatan interval dengan kedalaman. Kemiringan maksimal target didapatkan $40^{\circ}$ yang didapatkan dari analisa kualitatif model geologi. Kemudian, frekuensi maksimal yang digunakan yaitu $40 \mathrm{~Hz}$ sehingga dari perhitungan didapatkan CDP interval sebesar $25 \mathrm{~m}$.

Tabel 1. Variasi Parameter Desain Akuisisi 2D

\begin{tabular}{|l|c|c|}
\hline \multicolumn{2}{|c|}{ Variasi Parameter Desain Akusisi Seismik 2D } \\
\hline CDP Interval & $25 \mathrm{~m}$ & $12.5 \mathrm{~m}$ \\
\hline Fold Coverage & 45 & 30 \\
\hline Far Offset & 4500 & 2250 \\
\hline
\end{tabular}

Tabel 1 menunjukkan variasi parameter desain akuisisi seismik 2D. variasi tersebut kemudian akan digunakan untuk simulasi gelombang dengan menggunakan metode dinamik agar dapat dianalisa secara kualitatif reflektor yang dihasilkan. Konfigurasi survei yang digunakan yaitu off end, dimana posisi sumber berada pada salah satu sisi rangkaian hydrophone. Konfigurasi tersebut sangat sesuai untuk digunakan dalam akuisisi data seismik laut karena pengambilan data dilakukan bersamaan 


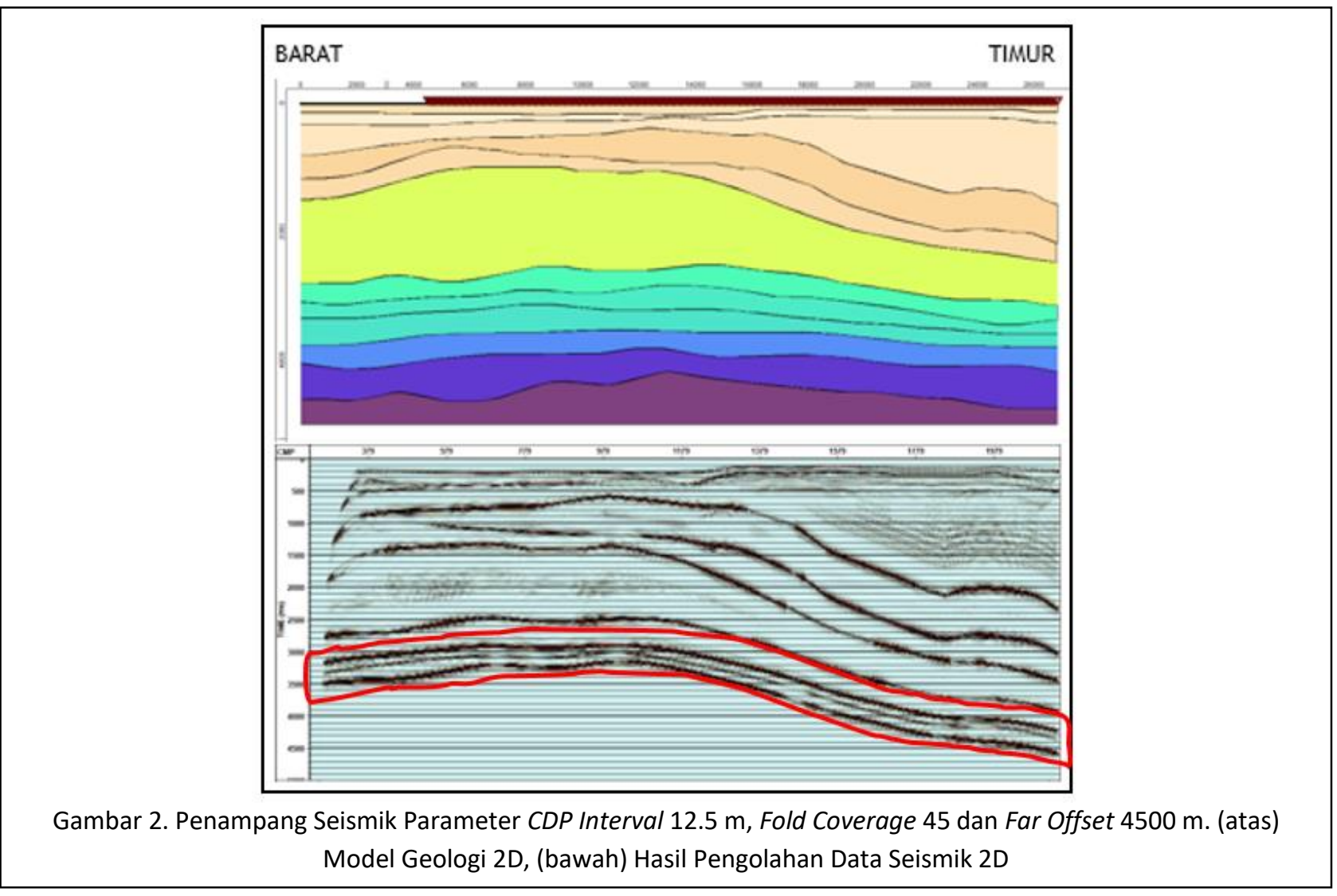

dengan jalannya kapal (moving survey) (Wibisono dkk., 2018). Nilai fold coverage dan far offset didapatkan dari perhitungan persamaan (4) dan (6).

Gambar 2 menunjukkan penampang seismik 2D dari simulasi gelombang desain akuisisi metode dinamik yang dianggap optimal karena mampu memberikan gambaran yang relatif mirip dengan model geologi 2D yaitu dengan parameter $C D P$ interval $12.5 \mathrm{~m}$ karena sangat memberikan kemenerusan reflektor yang tegas dan jelas, parameter fold coverage dengan nilai 45 karena mampu memberikan ketegasan reflektor yang baik, serta parameter far offset $4500 \mathrm{~m}$ karena dapat memberikan resolusi vertikal yang baik dalam artian jangkauan kedalaman gelombang dalam menggambarkan lapisan target (tanda warna merah). Pemilihan parameter yang optimal didukung oleh pernyataan Cordsen dkk tahun 2000, nilai CDP interval semakin rapat akan semakin baik $\mathrm{S} / \mathrm{N}$ rationya, nilai fold coverage semakin besar semakin baik $\mathrm{S} / \mathrm{N}$ ratio-nya (Cordsen dkk., 2000). Untuk nilai far offset dipilih tergantung pada target kedalaman, karena target kedalaman penelitian ini terdapat pada lapisan basement pada kedalaman diatas 4000 $\mathrm{m}$, maka dengan nilai far offset $4500 \mathrm{~m}$ mampu menjangkau target kedalaman dengan nilai maximum offset harus lebih besar daripada kedalaman target terutama pada kondisi geologi kompleks (Cordsen dkk., 2000).

Tabel 2. Desain Akuisisi Seismik 2D

\begin{tabular}{|l|c|}
\hline \multicolumn{2}{|c|}{ Parameter Desain Akuisisi Seismik 2D } \\
\hline CDP interval & $\mathbf{1 2 . 5} \mathbf{~ m}$ \\
\hline Fold Coverage & $\mathbf{4 5}$ \\
\hline Far Offset & $\mathbf{4 5 0 0 ~ \mathbf { ~ }}$ \\
\hline Interval Shot & $50 \mathrm{~m}$ \\
\hline Interval Receiver & $25 \mathrm{~m}$ \\
\hline Jumlah Shot & 447 \\
\hline Jumlah Hydrophone & 180 \\
\hline
\end{tabular}

Desain akuisisi 2D yang telah dipilih tersebut akan digunakan sebagai rekomendasi dalam penentuan parameter desain akuisisi 3D laut dengan menggunakan streamer. Parameter yang menjadi acuan untuk penentuan desain akuisisi seismik 3D laut ini yaitu jumlah streamer, interval streamer, dan interval hydrophone. Parameter jumlah streamer pernah dilakukan oleh Wibisono dkk., tahun 2018 untuk optimalisasi desain akuisisi 3D seismik laut 
dengan variasi parameter jumlah streamer 4, 6, dan 8 buah. Penelitian ini, parameter interval streamer, dan interval receiver juga digunakan untuk melihat pengaruh parameter tersebut terhadap jangkauan kedalaman

Tabel 3. Variasi Parameter Desain Akuisisi 3D

\begin{tabular}{|l|c|}
\hline \multicolumn{2}{|c|}{ Variasi Parameter } \\
\hline Jumlah Streamer & $6 ; 8 ; 10$ buah \\
\hline Interval Streamer & $100 \mathrm{~m} ; 200 \mathrm{~m}$ \\
\hline $\begin{array}{l}\text { Interval } \\
\text { Hydrophone }\end{array}$ & $25 \mathrm{~m} ; 12.5 \mathrm{~m}$ \\
\hline
\end{tabular}

Pada Tabel 3, Variasi jumlah streamer terdapat 2 (dua) variasi, interval streamer 2 (dua) variasi dan interval hydrophone/group interval 3 (tiga) variasi. Variasi tersebut dipilih mengikuti perkembangan teknologi dimana perkembangan jumlah streamer saat ini sudah menggunakan hingga 16 streamer (Vermeer, 2012), namun pada penelitian ini, digunakan 6-10 streamer. Pada umumnya, kebanyakan akuisisi streamer mernggunakan interval streamer $100 \mathrm{~m}$ untuk mendapatkan crossline sampling (Dondurur, 2018). Pada penelitian ini, digunakan dua variasi interval streamer $100 \mathrm{~m}$ dan $200 \mathrm{~m}$ untuk melihat jangkauan kedalaman. Interval hydrophone pada survei umumnya menggunakan $12.5 \mathrm{~m}$ dengan kelipatan $3.125 \mathrm{~m}$ (Dondurur, 2018). Dengan kelipatan tersebut digunakan variasi interval hydrophone $12.5 \mathrm{~m}$ dan 25 $\mathrm{m}$.

Untuk penembakan, penelitian ini menggunakan single source. Untuk konfigurasi penembakan tetap menggunakan konfigurasi off end dimana bentangan receiver mengikuti jalannya akuisisi (moving survey) dan tipe yang digunakan pada konfigurasi ini yaitu swath sail line. Variasi parameter desain akuisisi seismik 3D akan dikombinasikan sehingga didapatkan 12 (dua belas) variasi.

Tabel 4 menunjukkan variasi yang digunakan untuk penentuan parameter desain akuisisi seismik 3D metode statik. Variasi tersebut tetap mempertahankan parameter rekomendasi desain akuisisi 2D sebelumnya yaitu CDP interval $12.5 \mathrm{~m}$, fold coverage 45, dan far offset $4500 \mathrm{~m}$. pada seismik 3D, CDP interval disebut dengan bin size yaitu parameter yang menunjukkan titik pantul

Tabel 4. Variasi Parameter Desain Akuisisi Seismik 3D Laut

\begin{tabular}{|c|c|c|c|c|c|c|c|c|c|c|c|c|}
\hline Variasi ke- & 1 & 2 & 3 & 4 & 5 & 6 & 7 & 8 & 9 & 10 & 11 & 12 \\
\hline Jumlah Streamer & 6 & 8 & 10 & 6 & 8 & 10 & 6 & 8 & 10 & 6 & 8 & 10 \\
\hline Interval Streamer & $\begin{array}{l}\qquad \begin{array}{l}\circ \\
3\end{array} \\
3\end{array}$ & $\begin{array}{l}\overrightarrow{8} \\
8 \\
3\end{array}$ & $\begin{array}{l}5 \\
\circ \\
3\end{array}$ & $\begin{array}{l}\overrightarrow{8} \\
3 \\
3\end{array}$ & $\begin{array}{l}\qquad \begin{array}{l}\circ \\
3\end{array} \\
3\end{array}$ & $\begin{array}{l}5 \\
8 \\
3\end{array}$ & $\begin{array}{l}\tilde{O} \\
8 \\
3\end{array}$ & $\begin{array}{l}\text { No } \\
8 \\
3\end{array}$ & $\begin{array}{l}\text { No } \\
8 \\
3\end{array}$ & $\begin{array}{l}\text { N } \\
8 \\
3\end{array}$ & $\begin{array}{l}\tilde{8} \\
3 \\
3\end{array}$ & $\begin{array}{l}\tilde{O} \\
3\end{array}$ \\
\hline $\begin{array}{l}\text { Interval } \\
\text { Hydrophone }\end{array}$ & $\frac{\tilde{N}}{3}$ & $\frac{\tilde{N}}{3}$ & $\frac{N}{3}$ & $\begin{array}{l}\vec{E} \\
\dot{u} \\
3\end{array}$ & $\begin{array}{l}\vec{E} \\
\dot{u} \\
3\end{array}$ & $\begin{array}{l}\vec{E} \\
\text { un } \\
3\end{array}$ & $\frac{\tilde{N}}{3}$ & $\frac{\tilde{N}}{3}$ & $\frac{\tilde{N}}{3}$ & $\begin{array}{l}\vec{E} \\
\text { un } \\
3\end{array}$ & $\begin{array}{l}\vec{E} \\
\text { un } \\
3\end{array}$ & $\begin{array}{l}\vec{E} \\
\dot{u} \\
3\end{array}$ \\
\hline Interval Shot & $50 \mathrm{~m}$ & $50 \mathrm{~m}$ & $50 \mathrm{~m}$ & $50 \mathrm{~m}$ & $50 \mathrm{~m}$ & $50 \mathrm{~m}$ & $50 \mathrm{~m}$ & $50 \mathrm{~m}$ & $50 \mathrm{~m}$ & $50 \mathrm{~m}$ & $50 \mathrm{~m}$ & $50 \mathrm{~m}$ \\
\hline $\begin{array}{c}\text { Jumlah Hydrophone } \\
\text { /Streamer }\end{array}$ & 180 & 180 & 180 & 360 & 360 & 360 & 180 & 180 & 180 & 360 & 360 & 360 \\
\hline Jumlah Shot/Line & 487 & 487 & 487 & 487 & 487 & 487 & 487 & 487 & 487 & 487 & 487 & 487 \\
\hline Interval Lintasan & $\begin{array}{l}w \\
8 \\
3 \\
3\end{array}$ & $\begin{array}{l}8 \\
8 \\
3\end{array}$ & $\begin{array}{l}\text { ज } \\
8 \\
3\end{array}$ & $\begin{array}{l}\omega \\
8 \\
3 \\
3\end{array}$ & $\begin{array}{l}8 \\
8 \\
3\end{array}$ & $\begin{array}{l}\text { ज } \\
8 \\
3\end{array}$ & $\begin{array}{l}8 \\
8 \\
3\end{array}$ & $\begin{array}{l}\infty \\
8 \\
3\end{array}$ & $\begin{array}{l}\stackrel{5}{8} \\
8 \\
3\end{array}$ & $\begin{array}{l}8 \\
8 \\
3\end{array}$ & $\begin{array}{l}\infty \\
8 \\
3\end{array}$ & $\begin{array}{l}5 \\
8 \\
3 \\
3\end{array}$ \\
\hline Jumlah Lintasan & 56 & 42 & 34 & 56 & 42 & 34 & 28 & 21 & 17 & 28 & 21 & 17 \\
\hline Bin Size & 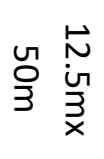 & 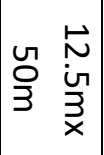 & 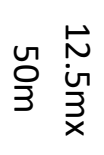 & 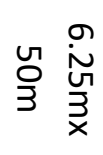 & 背 & 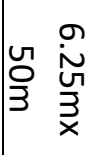 & 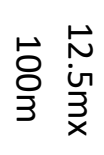 & 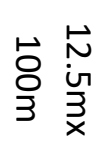 & 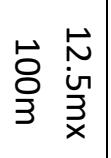 & 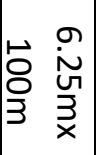 & 官 & 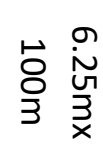 \\
\hline Fold Coverage & 45 & 45 & 45 & 45 & 45 & 45 & 45 & 45 & 45 & 45 & 45 & 45 \\
\hline Far Offset & $\begin{array}{l}\text { ज़ } \\
\text { ᄋ } \\
3\end{array}$ & $\begin{array}{l}\text { ज़ } \\
\text { ᄋ } \\
3\end{array}$ & $\begin{array}{l}\text { ज़ } \\
\text { ᄋ } \\
3\end{array}$ & $\begin{array}{l}\text { ज़ } \\
\text { О } \\
3\end{array}$ & $\begin{array}{l}\text { ज़ } \\
\text { ᄋ } \\
3\end{array}$ & $\begin{array}{l}\text { 봉 } \\
\text { ᄋ }\end{array}$ & $\begin{array}{l}\text { ज्ञ } \\
\text { Оे } \\
33\end{array}$ & $\begin{array}{l}\text { ज़ } \\
\text { 옹 } \\
33\end{array}$ & $\begin{array}{l}\text { ज्ञ } \\
\text { Оे } \\
33\end{array}$ & $\begin{array}{l}\text { ज़ } \\
\text { ᄋ } \\
3\end{array}$ & $\begin{array}{l}\text { ज्ञ } \\
\text { 옹 }\end{array}$ & $\begin{array}{l}\text { ज़ } \\
\text { ᄋ } \\
3\end{array}$ \\
\hline
\end{tabular}


(CDP) pada survei seismik 3D yang membentuk suatu bidang (Chaouch dan Mari, 2006) dan fold coverage terdapat 2 (dua) fold yaitu inline fold dan crossline fold. Namun, untuk akuisisi streamer nilai crossline fold bernilai 1 (satu) (Vermeer, 2012).

Parameter desain akuisisi seismik laut ini, terdapat pula parameter desain 3D lain seperti interval shot, jumlah hydrophone/streamer, jumlah shot/line, interval lintasan dan jumlah lintasan. Nilai parameter jumlah hydrophone/streamer tersebut ditentukan dari hasil perhitungan persamaan (6) dengan nilai far offset $4500 \mathrm{~m}$. Parameter interval shot didapat dari perhitungan persamaan (5) dengan menggunakan parameter interval hydrophone dan jumlah hydrophone/line serta acuan nilai fold coverage sebesar 45 . Nilai fold coverage pada akuisisi streamer sama dengan inline fold karena nilai crossline fold bernilai 1 (satu) disebabkan arah susunan streamer sejajar dengan arah shot line. Untuk parameter jumlah shot/line dan jumlah lintasan ditentukan dengan menyesuaikan dimensi template pengukuran dimana pada penelitian ini dimensi template disamakan dengan dimensi model geologi 3D. Penentuan nilai interval lintasan agar tidak terdapat gap data ditentukan dengan nilai setengah dari lebar streamer (Dondurur, 2018) dimana lebar streamer didapat dari perkalian jumlah streamer dengan interval. Nilai inline bin size dan crossline bin size dapat ditentukan dengan menggunakan persamaan (2) dan (3) dengan menggunakan parameter interval hydrophone dan interval streamer. Bin size $6.25 \mathrm{mx}$ $100 \mathrm{~m}$ dan $6.25 \mathrm{~m} \times 50 \mathrm{~m}$ (variasi ke- 4, 5, 6, 10, 11, 12) tidak menggunakan rekomendasi desain akuisisi 2D dengan nilai CDP interval 12.5 karena terdapat parameter interval hydrophone yang bernilai $12.5 \mathrm{~m}$ sedangkan pada persamaan (3) nilai inline bin size adalah setengah dari interval hydrophone sehingga nilai inline bin size yang didapat yaitu $6.25 \mathrm{~m}$.

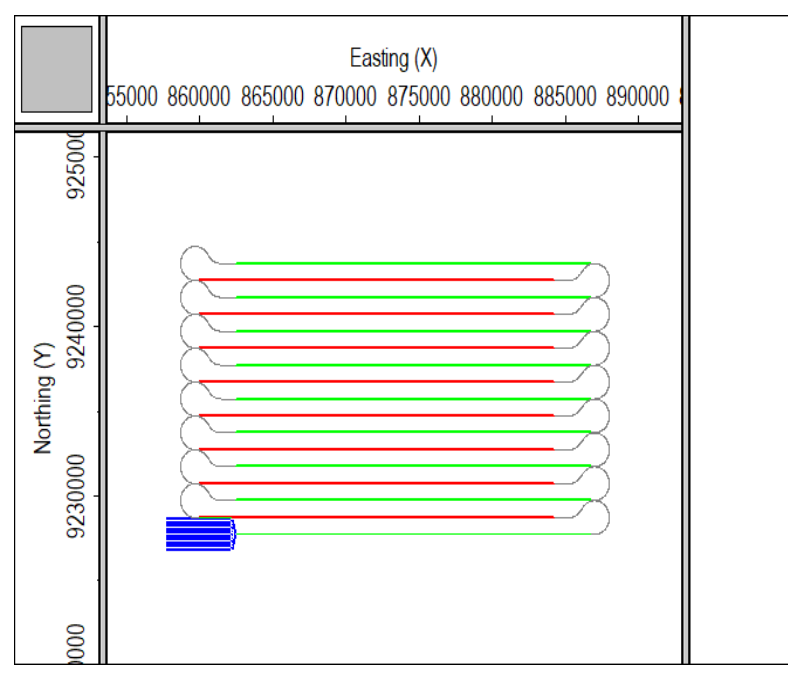

Gambar 3. Template Desain Akuisisi 3D Variasi ke-9

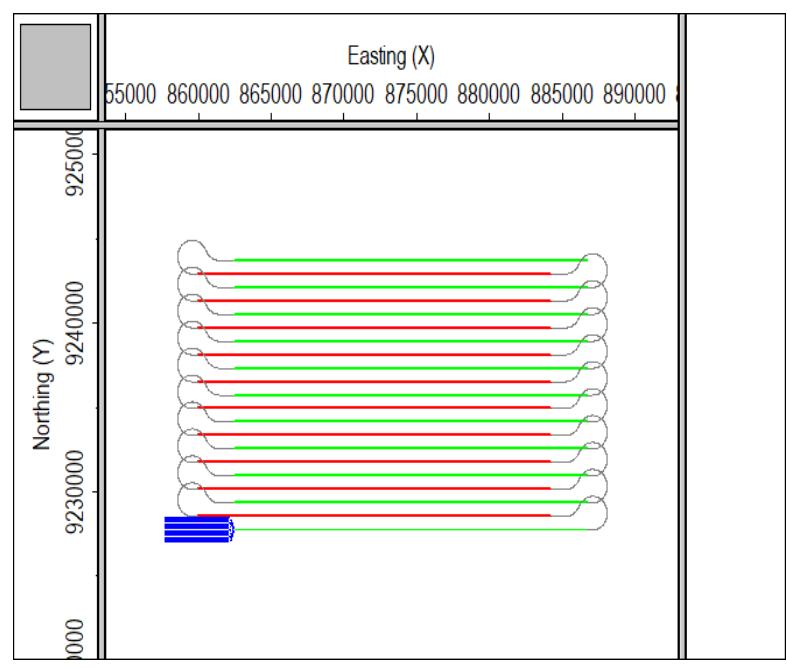

Gambar 4. Template Desain Akuisisi 3D Variasi ke11

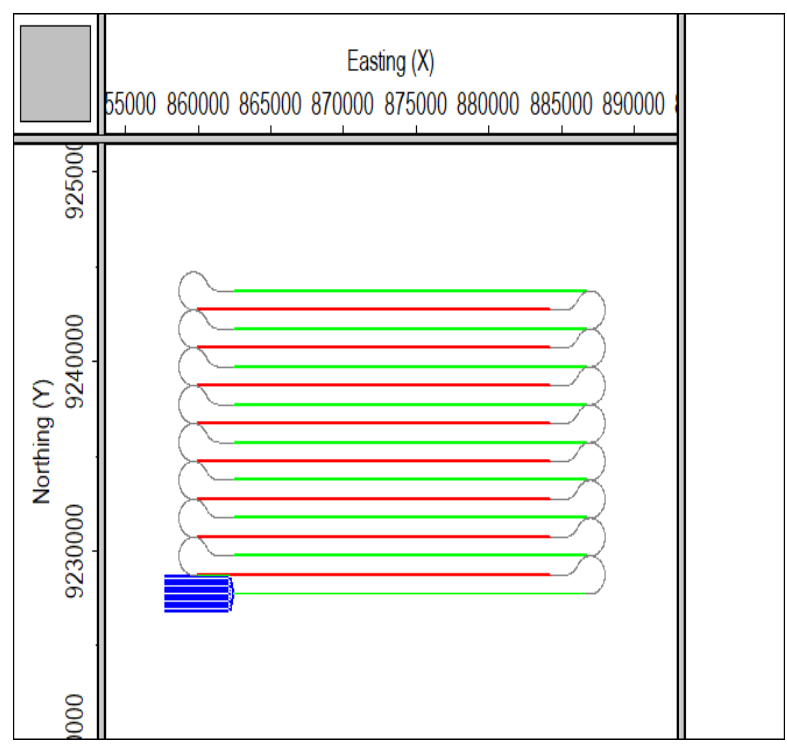

Gambar 5. Template Desain Akuisisi 3D Variasi ke12 
Gambar 3 menunjukkan template, nilai 3D fold, nilai far offset dari variasi ke-9 (jumlah streamer 10, interval streamer $200 \mathrm{~m}$, dan interval hydrophone 25 $\mathrm{m}$ ) sedangkan Gambar 4 untuk variasi ke-11 (jumlah streamer 8 buah, interval streamer $200 \mathrm{~m}$, dan interval hydrophone $12.5 \mathrm{~m}$ ) dan Gambar 5 untuk variasi ke-12 (jumlah streamer 10 buah, interval streamer $200 \mathrm{~m}$, dan interval hydrophone $12.5 \mathrm{~m}$ ). Arah penembakan ke arah Barat ditunjukkan garis warna merah pada gambar dan sebaliknya, garis warna hijau menunjukkan arah penembakan ke Timur, kapal yang membawa streamer ditunjukkan oleh garis warna biru. Template tersebut menggunakan konfigurasi tipe sail line dengan pattern antiparallel dimana kapal berjalan ke shot line berikutnya yang berdekatan dari shot line yang telah diakuisisi dan memulai penembakan dengan arah berlawanan (Dondurur, 2018). Penembakan dilakukan dengan orientasi arah Barat-Timur, arah akuisisi ini ditentukan karena dari model geologi 3D arah dipping dominan dengan arah Barat-Timur.

Parameter jumlah streamer dan interval streamer dapat dilihat pengaruhnya pada template berdasarkan variasi parameter desain akuisisi 3D tersebut yaitu semakin banyak jumlah streamer dan besar interval streamer yang digunakan semakin sedikit jumlah lintasan yang digunakan. Sedangkan nilai interval hydrophone tidak berpengaruh besar pada template. Pengaruh parameter tersebut pada template dipertimbangkan untuk penentuan parameter optimal karena dengan hasil yang sama diperlukan parameter dengan biaya dan waktu yang lebih efisien dan didapatkan variasi 8, 9, 11, dan 12 (lihat Tabel 4) dianggap paling efisien dari tinjauan jumlah lintasan yang paling sedikit dan paling berpengaruh pada biaya dan waktu. Namun, untuk lebih mendapatkan parameter desain akuisisi seismik 3D metode statik yang optimal, perlu dilakukan analisa lain setiap variasi yaitu analisa trace count terhadap offset.

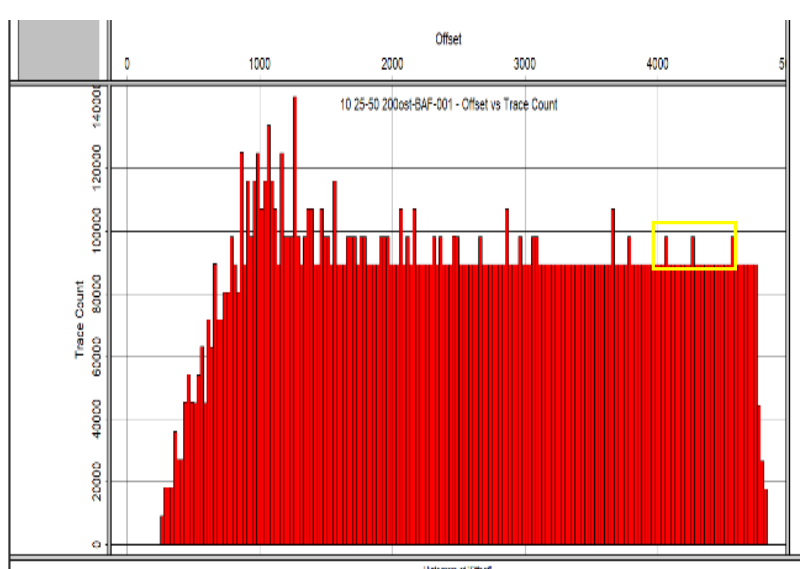

Gambar 6. Histogram Trace Count vs Offset variasi ke-9

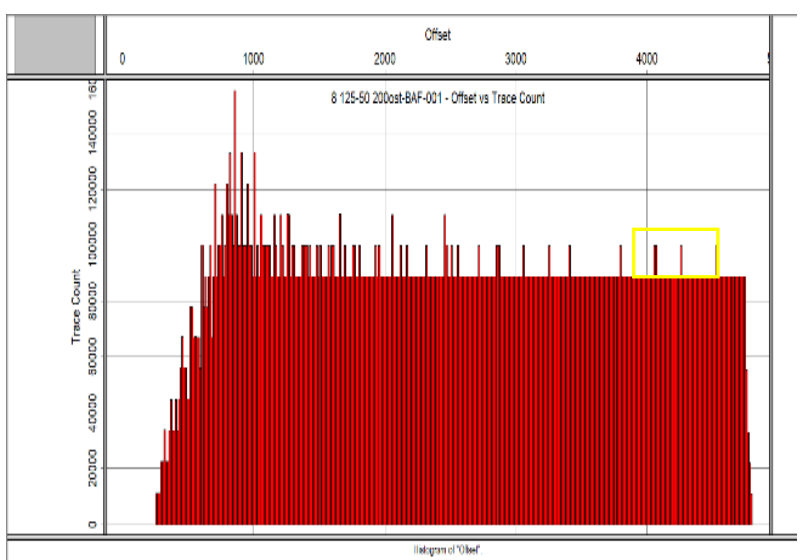

Gambar 7. Histogram Trace Count vs Offset variasi ke-11

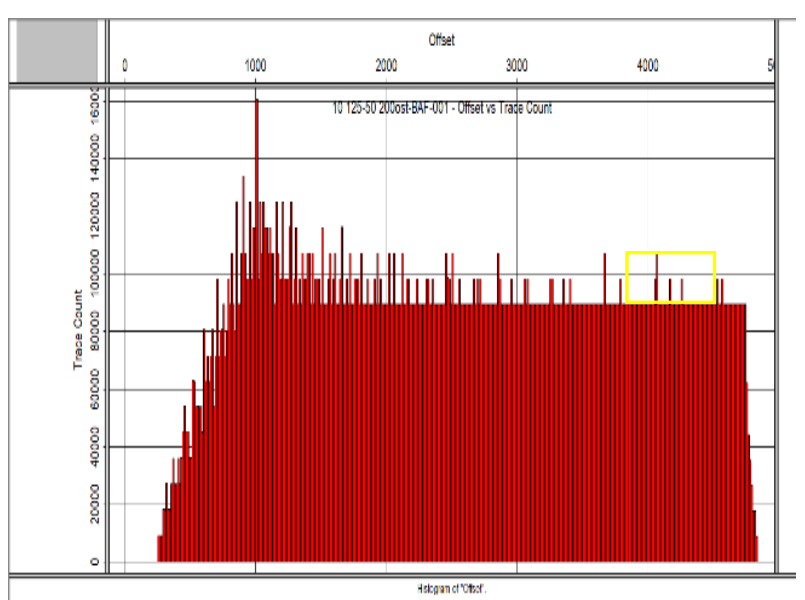

Gambar 8. Histogram Trace Count vs Offset variasi ke-12

Pada Gambar 6 sampai 8 terdapat diagram hubungan antara trace count dengan offset variasi ke-9, 11, dan 12. Ketiga variasi tersebut merupakan variasi yang dipilih sebagai parameter paling optimal. Diagram tersebut merupakan hubungan banyaknya 


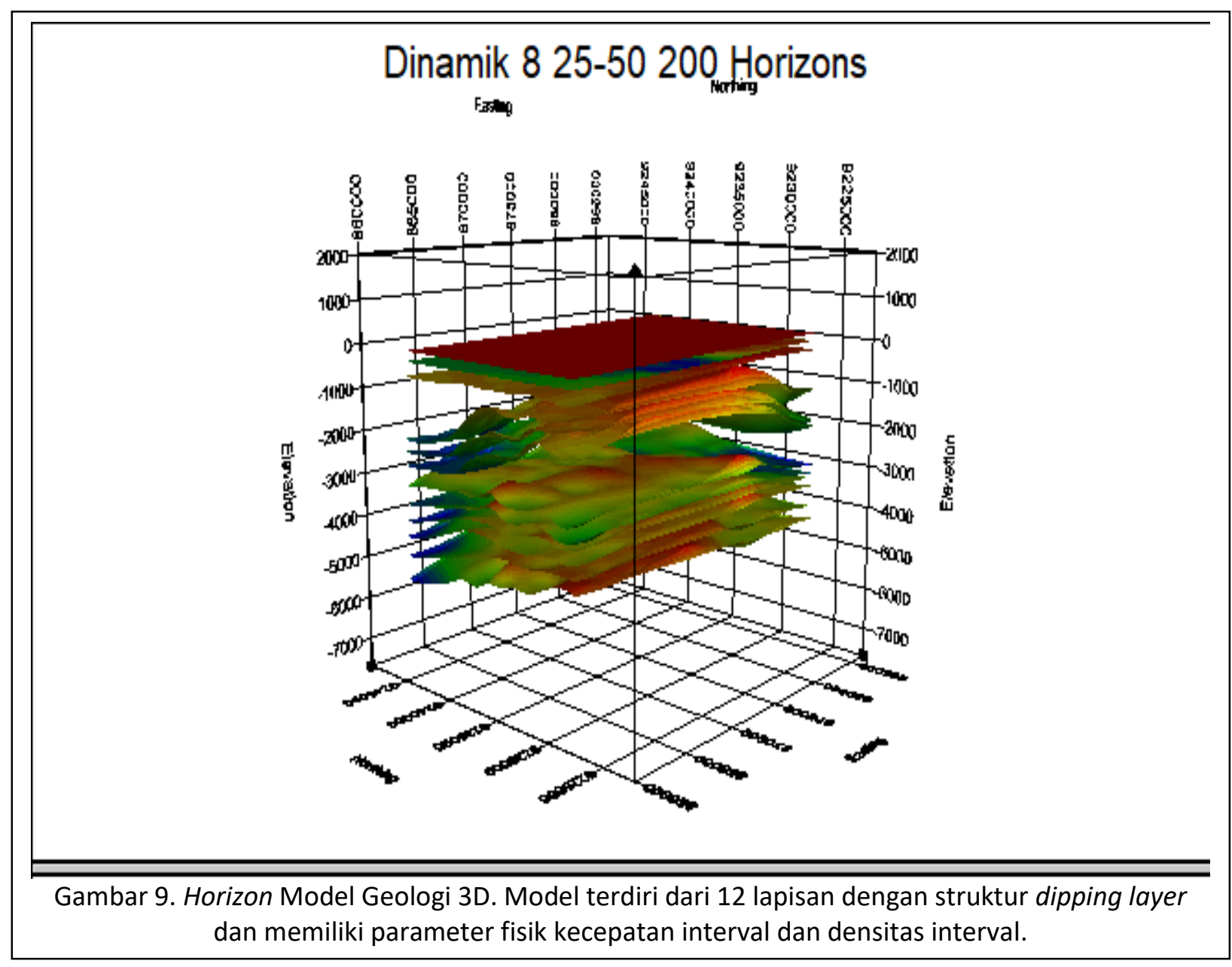

jumlah traces pada tiap offset. Untuk mendapatkan jangkauan target kedalaman tersebut nilai offset tidak boleh kurang dari $4000 \mathrm{~m}$ karena semakin besar nilai far offset maka jangkauan kedalaman atau resolusi vertikal akan semakin baik. Ketiga variasi telah dipilih karena terdapat beberapa trace tinggi yang berkumpul pada offset lebih dari $4000 \mathrm{~m}$ yang ditunjukkan oleh kotak warna kuning.

Setelah dilakukan analisa terhadap 3 (tiga) variasi parameter desain akuisisi seismik 3D laut yang telah dipilih, Parameter jumlah streamer berpengaruh pada distribusi trace pada offset. Semakin banyak jumlah streamer semakin banyak traces yang terakumulasi pada offset tertentu. Kemudian, semakin besar nilai interval streamer, jangkauan offset dengan trace yang terkumpul lebih jauh. Sedangkan parameter interval hydrophone akan mempengaruhi inline bin size sehingga semakin kecil interval hydrophone banyak kelipatan trace count. Tiga variasi parameter yang telah dipilih tersebut digunakan untuk dilakukan metode dinamik. Metode dinamik menggunakan iluminasi pada target kedalaman dengan penembakan berdasarkan konfigurasi template tiap variasi. Proses iluminasi menggunakan model geologi 3D.

Gambar 10 sampai 12 merupakan hasil dari simulasi iluminasi berupa illumination map dari ketiga variasi. Illumination map menampilkan persebaran nilai 3D fold dari lapisan target yaitu basement. Besar tidak nya nilai fold pada illumination map berdasar dari banyaknya ray yang terpantul pada suatu bin size lapisan basement setelah melewati 11 horizon diatasnya yang memiliki pengaruh pada keadaan struktur dan parameter fisik (kecepatan interval dan densitas)

Perlu dianalisa untuk mendapatkan parameter desain akuisisi seismik 3D yang paling optimal sebagai hasil dari penelitin ini. Analisa yang dilakukan yaitu analisa range $3 D$ fold. Illumination map variasi ke-9 memiliki nilai fold tertinggi sebesar 368 dan nilai terkecil 0. Untuk illumination map variasi ke-11, fold tertinggi bernilai 242 dan fold terendah bernilai 0 (nol). Sedangkan illumination map variasi ke-12, fold 
tertinggi bernilai 513 dan fold terendah bernilai 0 (nol). untuk mendapatkan gambaran lapisan target dengan reflektor jelas, maka fold coverage harusnya merata dengan artian perbedaan persebaran nilai fold tidak terlalu tinggi. Illumination map variasi ke11 memiliki perbedaan nilai fold yang paling kecil daripada kedua illumination map variasi lainnya maka variasi ke-9 (jumlah streamer 8 buah, interval streamer $200 \mathrm{~m}$, dan interval hydrophone 12.5) dianggap paling optimal.

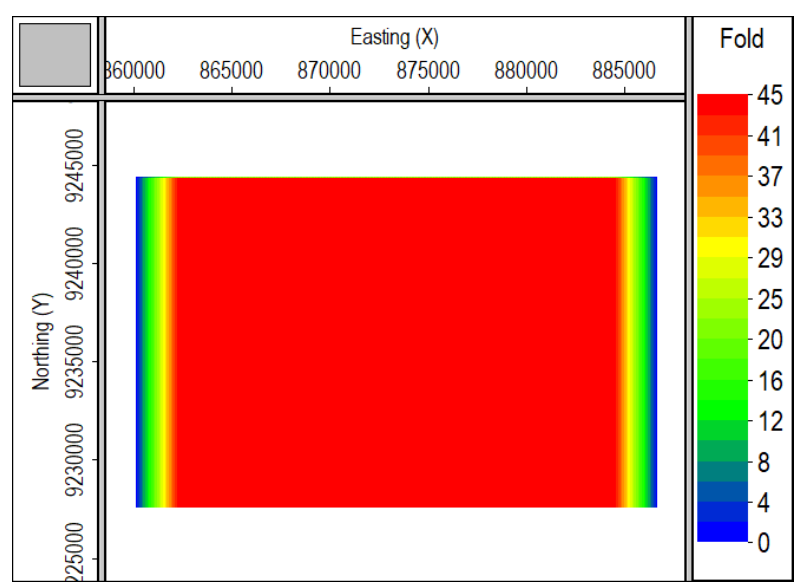

Gambar 13. 3D Fold Variasi ke-11 (Metode Statik)

Jika dibandingkan degan metode statik, nilai 3D fold variasi ke-11 metode statik (Gambar 13) merata dengan nilai 45 pada bagian tengah karena kondisi bawah pemukaan diasumsikan datar (flat) sedangkan metode dinamik (Gambar 11), nilai fold tetap dominan bernilai 45 namun variasi nilainya bervariasi tiap bin dikarenakan pengaruh lapisanlapisan atas menyebabkan ray terefleksi, terefraksi dan diteruskan hingga memantul pada lapisan basement. Setelah penentuan parameter desain akuisisi seismik 3D laut menggunakan metode statik dan dinamik didapatkan parameter desain akuisisi seismik 3D menggunakan statik dinamik dianggap paling direkomendasikan daripada hanya menggunakan metode statik.

\section{PENUTUP}

Berdasarkan penelitian yang telah dilakukan, maka dapat ditarik kesimpulan bahwa desain akuisisi seismik 3D laut yang optimal memiliki parameter sebagai berikut:

- Konfigurasi

: Off end, sail line type

- Bin Size : $6.25 \mathrm{~m} \times 100 \mathrm{~m}$
- Fold Coverage : :45

- Far Offset : 4500 meter

- Jumlah Streamer : 8 buah

- Interval Streamer : 200 meter

- Interval Hydrophone: 12.5 meter

- Interval Shot :50 meter

- Jumlah Hydrophone

$$
\text { /Streamer : } 360 \text { buah }
$$

- Jumlah Shot/Line : 487 buah

- Interval Lintasan $: 800 \mathrm{~m}$

- Jumlah Lintasan : 21 lintasan

Metode statik mengasumsikan kondisi bawah permukaan dalam keadaan flat (datar) sehingga range nilai fold relatif sama, sedangkan metode dinamik mempertimbangkan kondisi bawah permukaan dengan analisa range nilai fold yang bervariasi pada lapisan target sehingga jatuhnya raypath terpengaruh oleh lapisan yang dilalui ray tersebut. Oleh karena itu, pengoptimalan menggunakan metode dinamik lebih direkomendasikan dengan asumsi simulasi ray yang dilakukan lebih mendekati kondisi sebenarnya. Selain itu, dapat ditambahkan variasi arah penembakan untuk analisa azimuth distribution, serta mempertimbangkan segi biaya operasional dari desain akuisisi yang dibuat.

\section{DAFTAR PUSTAKA}

Banuboro, A. (2017), Desain Parameter Akuisisi Seismik 3d Untuk Eksplorasi Hidrokarbon Di Lingkungan Vulkanik Dengan Dengan Analisa Metode Dinamik Dan Statik Pada Cekungan Jawa Barat Bagian Utara, Undergraduate, Institut Teknologi Sepuluh Nopember. Diambil dari http://repository.its.ac.id/42206/.

Chaouch, A. dan Mari, J.L. (2006), "3-D Land Seismic Surveys: Definition of Geophysical Parameter", Oil \& Gas Science and Technology - Revue de I'IFP, Vol.61, No.5, hal. 611-630. http://doi.org/10.2516/ogst:2006002.

Cordsen, A., Galbraith, M. dan Peirce, J. (2000), Planning Land 3-D Seismic Surveys, Society of Exploration Geophysicists. http://doi.org/10.1190/1.9781560801801.

Dondurur, D. (2018), "Marine Seismic Data Acquisition", dalam Acquisition and Processing of Marine Seismic Data, Elsevier, hal. 37-169. 
http://doi.org/10.1016/B978-0-12-811490-

2.00002-5.

Lubis, R. dan Mulyatno, B.S. (2018), OPTIMALISASI DAN

ANALISIS DESAIN PARAMETER SEISMIK 3D

DARAT, hal. 18.

Vermeer, G.J.O. (2012), 3D Seismic Survey Design, Second Edition, Society of Exploration Geophysicists. http://doi.org/10.1190/1.9781560803041.

Wibisono, B., Utama, W. dan Syaifuddin, F. (2018), "Desain Akuisisi Seismik Laut 3D Untuk Eksplorasi Hidrokarbon Dengan Menggunakan Metode Enhanced Static", Jurnal Geosaintek, Vol.4, No.3, hal. 75. http://doi.org/10.12962/j25023659.v4i3.4509. 